\title{
Exploring Leadership in E-commerce Adoption in Australian SMEs
}

\author{
Scupola, Ada
}

Published in:

Leadership in the Digital Enterprise

\section{Publication date:}

2010

\section{Document Version}

Early version, also known as pre-print

Citation for published version (APA):

Scupola, A. (2010). Exploring Leadership in E-commerce Adoption in Australian SMEs. In P. Yoong (Ed.), Leadership in the Digital Enterprise: Issues and Challenges (pp. 118-131). Idea Group Publishing.

\section{General rights}

Copyright and moral rights for the publications made accessible in the public portal are retained by the authors and/or other copyright owners and it is a condition of accessing publications that users recognise and abide by the legal requirements associated with these rights.

- Users may download and print one copy of any publication from the public portal for the purpose of private study or research.

- You may not further distribute the material or use it for any profit-making activity or commercial gain.

- You may freely distribute the URL identifying the publication in the public portal.

Take down policy

If you believe that this document breaches copyright please contact rucforsk@kb.dk providing details, and we will remove access to the work immediately and investigate your claim. 


\section{Leadership in the Digital Enterprise: Issues and Challenges}

Pak Yoong

Victoria University of Wellington, New Zealand 


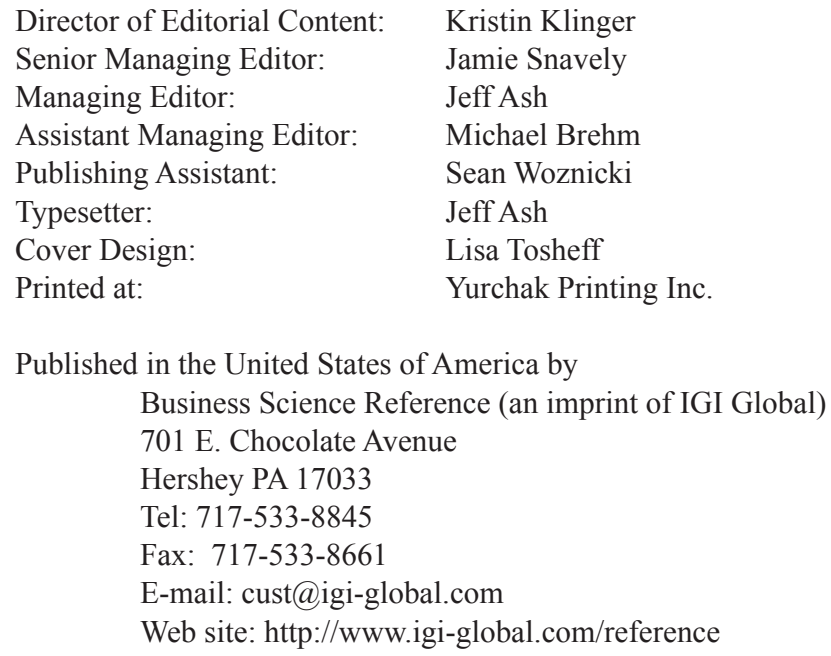

Copyright (C) 2010 by IGI Global. All rights reserved. No part of this publication may be reproduced, stored or distributed in any form or by any means, electronic or mechanical, including photocopying, without written permission from the publisher.

Product or company names used in this set are for identification purposes only. Inclusion of the names of the products or companies does not indicate a claim of ownership by IGI Global of the trademark or registered trademark.

Library of Congress Cataloging-in-Publication Data

Leadership in the digital enterprise : issues and challenges / Pak Yoong, editor.

p. cm.

Includes bibliographical references and index.

Summary: "This book presents a comprehensive collection of the most current research on various aspects, roles, and functions of digital enterprises"--Provided by publisher.

ISBN 978-1-60566-958-8 (hardcover) -- ISBN 978-1-60566-959-5 (ebook) 1. Knowledge management. 2. Leadership. 3. High technology industries. I. Yoong, Pak, 1945- II. Title.

HD30.2.L427 2010

658.4'092--dc22

2009012908

British Cataloguing in Publication Data

A Cataloguing in Publication record for this book is available from the British Library.

All work contributed to this book is new, previously-unpublished material. The views expressed in this book are those of the authors, but not necessarily of the publisher. 


\title{
Chapter 9 \\ Exploring Leadership in E-Commerce Adoption in Australian SMEs
}

\author{
Ada Scupola \\ Roskilde University, Denmark
}

\begin{abstract}
This chapter presents the results of a study investigating leadership and leadership styles in e-commerce adoption in small and medium size enterprises in Australia. The results show that top management and CEO'leadership have a key role in small and medium size enterprises (SMEs) in developing a vision for e-commerce adoption and that the dominant leadership style is directive with some signs of consultative. Furthermore the study shows that e-commerce adoption is becoming a strategic process and in this process top management is taking into consideration both the organizational knowledge and the knowledge of external consultants.
\end{abstract}

\section{INTRODUCTION}

Technological development is impacting the business landscape by providing new ways and opportunities to conduct business. In the last decade e-commerce has especially created new possibilities to change ways of doing businesses or create new business models. In such a changing environment the role of the leader is becoming vital. "Leaders as opposed to managers are creating the visions and make the necessary plans and steps to keep their organizations competitive. In the past the role of managers was to organize, delegate and get the job done. Nowadays companies need leaders that can establish visions and can guide the company in turbulent times (Cope and Waddell, 2001; Jago, 1982; Bower and Gilbert, 2007). This is especially true for small and medium size enterprises (SMEs) which are believed to highly benefit from e-commerce (OECD, 2002). There is much disagreement about how to classify SMEs. In this article the definition of the Australian Bureau of Statistics (ABS) is adopted according to which a small and medium size business is any business employing less than

DOI: $10.4018 / 978-1-60566-958-8 . c h 009$ 
200 employees (www.abs.gov.au). Also different definitions of e-commerce can be found in the literature. In this study e-commerce is defined as the business activities conducted using electronic data transmissions via the WWW and the focus is on business-to-business e-commerce in opposition to business-to-consumer e-commerce.

Most of the literature on SMEs' e-commerce adoption focuses on factors that affect the adoption decisions or factors that distinguish adopters from non adopters (e.g. Jeyaraj et al., 2006; Sabherwal et al., 2006). Previous studies have also found that the decision to adopt is influenced by environmental factors such as competitive pressure or suppliers' pressure (Thong, 1999); organizational factors such as top management support or employees knowledge (Palvia and Palvia, 1999) and technological factors such as perceived benefits of the technology (e.g. Iacovou et al., 1995) . More recently, studies are focusing on the strategic impact (e.g. Drew, 2003) or the impact of the perceived strategic value of ecommerce on the adoption decision (e.g. Grandon and Pearson, 2003). However the role ofleadership in e-commerce adoption has not received much attention in the literature on e-commerce and IT adoption, which is the motivation for this study. The basic research question is:" What is the role of leadership in e-commerce adoption in small and medium size enterprises and what are the predominant leadership styles?" This question is important because the major reasons for adopting e-commerce are creating or maintaining a competitive advantage, improving customer satisfaction and keeping pace with competition as a survey conducted by Cope and Waddell (2001) about the main goals for adopting e-commerce in various industries shows.

The chapter is structured as follows. The next section presents a literature review of ICT adoption frameworks in SMEs, while the following section discusses the role of leadership and presents the theoretical framework used in the paper. This is followed by a description of the research design, the data collection process, and the companies' background. The remainder of the chapter presents the analysis, discussion of the results, implications for practice, and conclusions and limitations.

\section{THEORETICAL BACKGROUND}

\section{Adoption of Innovation}

A fundamental approach to studying the adoption of new technologies is the diffusion of innovations (Rogers, 1995). Organizational innovations can be defined as the development and implementation of products, technologies, systems or ideas that are new to the company (Rogers, 1995). Therefore e-commerce can be defined as a type of innovation for the company adopting it. Prior studies in organizational innovation and diffusion of information technology suggest a number of factors that affect adoption and diffusion of information technology and e-commerce within a company (e.g. Kurnia \& Johnston, 2000; Chau \& Tam, 1997; Premkumar \& Ramamurthy, 1995; Grandon and Pearson, 2003). Even though the factors affecting ICT and e-commerce adoption have been grouped into different categories (see Jeyaraj et al., 2006 for a thorough literature review), many authors (e.g. Kurnia \& Johnston, 2000; Scupola, 2009) show that they can be mainly categorized according to the three contexts of Tornatzky and Fleischer's (1990) model: the environmental context, the organizational context and the technological context. Similarly we use these three contexts in organizing the literature review in this chapter as shown in Table 1.

\section{External Environmental Context}

The external environment is the arena in which an organization conducts its business. Tornatsky and Fleischer (1990) distinguish three main groups of factors within this context: industry characteristics such as competition and customer supplier rela- 
Table 1. Factors affecting adoption of e-commerce, EDI and IT/IS in SMES

\begin{tabular}{|c|c|c|}
\hline Context & Factors & Authors \\
\hline Environmental Context & $\begin{array}{l}\text { Competitiveness } \\
\text { Competitive Pressure } \\
\text { Customer/Supplier Pressure } \\
\text { Government Influence } \\
\text { Quality of access to E-commerce Related Ser- } \\
\text { vices } \\
\text { Trade Associations } \\
\text { Public Administration } \\
\text { External Pressure } \\
\text { Environmental Characteristics }\end{array}$ & $\begin{array}{l}\text { Lertwongsatien and Wongpinunwatana (2003) } \\
\text { Scupola (2003) } \\
\text { Iacovou et al. (1995) } \\
\text { Palvia \& Palvia (1999) } \\
\text { Kuan and Chau (2001) } \\
\text { Thong (1999) }\end{array}$ \\
\hline Organizational Context & $\begin{array}{l}\text { Size } \\
\text { Innovation Champion } \\
\text { Top Management Support } \\
\text { Existence of IT Department } \\
\text { Employees IT Knowledge } \\
\text { Organizational Readiness } \\
\text { Owner Related Factors } \\
\text { Organizational Characteristics } \\
\text { CEO Characteristics }\end{array}$ & $\begin{array}{l}\text { Lertwongsatien and Wongpinunwatana (2003) } \\
\text { Scupola (2003) } \\
\text { Mirchandani and Motwani (2001) } \\
\text { Iacovou et al. (1995) } \\
\text { Palvia \& Palvia (1999) } \\
\text { Kuan and Chau (2001) } \\
\text { Thong (1999) }\end{array}$ \\
\hline Technological Context & $\begin{array}{l}\text { Perceived Benefits } \\
\text { Perceived Compatibility } \\
\text { Perceived Barriers } \\
\text { Perception of IS Attributes }\end{array}$ & $\begin{array}{l}\text { Lertwongsatien and Wongpinunwatana (2003) } \\
\text { Scupola (2003) } \\
\text { Mirchandani and Motwani (2001) } \\
\text { Iacovou et al. (1995) } \\
\text { Thong (1999) }\end{array}$ \\
\hline
\end{tabular}

tionships, technology support infrastructure and government intervention. Iacovou et al. (1995) found that external pressures, divided into competitive pressure and imposition by trading partners, were determinant in SMEs' EDI adoption. Competitive pressure was also found important by Thong (1999). Similarly Kuan and Chau (2001) in a study to understand factors distinguishing EDI adopters from non adopters, found that adopters perceive a higher government pressure and a lower industry pressure then non adopters. Finally Scupola (2003) found that government role, public administration, trade associations and suppliers pressure had an important role in SMEs' e-commerce adoption within the external environment in Southern Italy.

\section{Organizational Context}

The organizational context represents the factors internal to an organization influencing an innovation adoption. These factors are a source of structures, processes and attributes that constrain or facilitate adoption (Tornatzky and Fleischer, 1990). Many factors belonging to this context have been found important in explaining information technology innovation and e-commerce adoption. For example, Iacovou et al. (1995) identified organizational readiness, operationalized as financial and technological resources of the firm as a major factor in SMEs' EDI adoption. Palvia and Palvia (1999) conclude that owner characteristics have a greater impact on ICT satisfaction, while other factors such as training and education represent reasons for dissatisfaction.

These results are also supported by Thong (1999) that showed that the CEO characteristics have a major importance in IS adoption and by Kuan and Chau (2001). Mirchandani and Motwani (2001) include employees' IT knowledge and top management support as factors distinguishing small business e-commerce adopters from non adopters, while Scupola (2003) in addition found that the innovation champion and financial 
resources were also relevant factors. Finally, Lertwongsatien and Wongpinunwatana (2003) show that adopters, prospectors and laggards differ significantly on the extent of top management support and existence of the IT department.

\section{Technological Context}

The technological context represents the pool of technologies available to a firm for adoption, which can be both the technologies available on the market and the firms' current equipment. The decision to adopt a technology depends not only on what is available on the market, but also on how such technologies fit with the technologies that a firm already possesses (Tornatsky and Fleischer, 1990; Chau and Tam, 1997). Many studies have investigated the impact of the innovation characteristics on the innovation process. For example Iacovou et al. (1995) states that relative advantage (e.g. perceived benefits and barriers), compatibility (both technical and organizational) and trialability (e.g. pilot tests) are among the main attributes. This was also supported by Mirchandani and Motwani (2001) and partially by Scupola (2003). Lertwongsatien and Wongpinunwatana (2003) find that prospectors and adopters are significantly different from laggards in perceived benefits and perceived compatibility.

\section{THE IMPORTANCE OF LEADERSHIP IN SMES' E-COMMERCE ADOPTION}

As showed by the above literature review, many studies (e.g. Jeyaraj et al., 2006; Thong, 1999; Thong and Yap, 1996) have pointed out the importance of the organizational context in information technology innovation and within this context have investigated the effects of the organizational characteristics and individual characteristics. Within the organizational characteristics, previous e-commerce adoption research has often focused on the characteristics of the CEO (e.g. Sabherwal et al., 2006). The argument goes that he/she has a major role in the business, which is especially important in SMEs where the CEO is often also the owner and is responsible for the survival of the business (Thong and Yap, 1995). Examples of characteristics investigated are CEO's IT knowledge and attitude towards IT innovations. For example Thong (1999) explored the role of CEO's IT knowledge and innovativeness in IT adoption. However CEOs in small companies are often not especially knowledgeable about information technology, which can be a major barrier to adoption (e.g. Cragg and King, 1993). Finally previous literature (e.g. Thong, 1999; Thong and Yap, 1995) pointed out that the CEO is generally the single point of authority, usually does not share information with other organization's employees and suggest that the CEO is the only one with access to the information needed to identify new opportunities, therefore management support is crucial for innovation adoption. CEO and top management, and especially their leadership, becomes even more important considering that small and medium size businesses have limited slack resources to invest in information technology and e-commerce (e.g. Iacovou et al., 1995). There are many definitions of leadership. The most common one is that "leadership is both a process and a property. The process of leadership is the use of noncoercive influence to direct and coordinate the activities of the members of an organized group towards the accomplishment of group objectives. As a property, leadership is the set of qualities or characteristics attributed to those who are perceived to successfully employ such influence" (Jugo, 1982). Leadership (Ready, 2004; Kotter, 2001; Goleman, 2004) might be especially important in establishing a vision and enforcing organizational rules and policy to facilitate e-commerce adoption in the organization (e.g. Scupola, 2008). In a seminal article, Kotter (2001) states that leadership is about coping with change, while management is about copying with complexity. An important leadership role 
is setting a direction, a vision for the company in specific domains, including for example ecommerce adoption. According to Kotter (2001, p. 87) "what's crucial about a vision is not its originality but how well it serves the interests of important constituencies-customers, stockholders, employees" and how it can be translated into a realistic company strategy". Another important role of leadership is aligning people in such a way that everybody in the company supports the established vision. This is very important as modern organizations are characterized more then ever by interdependence among employees and managers by their work, management systems and technology. Finally it is important that leaders are able both to motivate others and develop others' leadership skills (Kotter, 2001; Zaleznik, 2004; Ready, 2004). There are different theoretical approaches to leadership. The most important are universal vs. contingent theories of leadership and the ones focusing on leadership styles such as autocracy vs. democracy (Jugo, 1982). Here we focus on leadership styles. Research on leadership shows that leadership and leadership styles might be contingency-based and culturally embedded (e.g. Jago, 1982). Therefore, since this empirical investigation has been conducted in Australia, a model based on a study of Australian firms has been chosen here for the investigation: the Dunphy and Stace (1990) model.

\section{The Dunphy and Stace (1990) Model of Leadership Styles and Change Management}

This model provides a comprehensive method to analyze different levels and degrees of change and leadership styles. By drawing on the theory of change management by Dunphy and Stace (1990) and the study conducted by Cope and Waddell (2001) about auditing of leadershipstyles ine-commerceadoption, I use the following conceptualization of leadership styles and types of organizational change to investigate e-commerce leadership in this study:
1. Collaborative. This involves widespread employees'participation in important decisions about the organizations' future, and about the means of bringing about the organizational change.

2. Consultative. This style involves consultation with employees, primarily about the means of conducting the organizational change, with their possible limited involvement in setting goals of relevance to their area of expertise or responsibility.

3. Directive. This leadership style involves the use of managerial authority and direction as the main form of decision making about the organization's future, and about the means of bringing about organizational change.

4. Coercive. This style of leadership involves managers/executives or outside parties forcing or imposing change on key groups in the organization (Dunphy and Stace, 1993, p. 6).

Also Dunphy and Stace (1990) identified four types of organizational change an organization can undertake as a response to different stimuli, including the external environment. In e-commerce adoption, such stages can be described as follows:

1. "Fine Tuning". Organizational change which is an ongoing process characterized by fine tuning occurring in different departments to prepare for electronic adoption and use. Personnel is being developed and trained to suit the organizational adoption of e-commerce and some groups are formed within the organization to focus on e-commerce.

2. Incremental Adjustment. Organizational change which is characterized by incremental adjustments to the changing environment. The emphasis is here shifted from traditional business to a new way of conducting business (e-business). Such change involves distinct modifications (but not radical change) to 
corporate business strategies, structures and management processes.

3. Modular transformation. Here organizational transformation is characterized by the major realignment of one or more department to embrace e-commerce. The process of radical change is focused on one of these subparts as for example introduction of significantly new process technologies affecting key departments or ways of conducting business.

4. Corporate Transformation. Organizational change which includes a radical transformation of the business strategies to include also e-commerce and many processes and procedures have been changed to accommodate e-commerce.

Even though these leadership styles and organizational transformation types were not developed originally by keeping the small ad medium size enterprises in mind, the assumption is made here that the four leadership styles mentioned above can be of use to investigate leadership in SMEs. However it is clear that parts of the four transformational stages are mainly characteristic of bigger companies. This is taken into consideration in the analysis.

\section{RESEARCH APPROACH AND DATA COLLECTION}

In order to investigate the role of leadership in e-commerce adoption in small and medium size businesses, the case study method (Yin, 2003) has been used. Yin (2003) defines a case study as "an empirical inquiry that investigates a contemporary phenomenon within its reallife context and relies on multiple sources of evidence (p. 13)". By following Yin (2003), the case study method can be used in this study to corroborate existing research, learn the state of the art of the role of leadership in SMEs' e-commerce adoption, and understand the na- ture and complexity of such a phenomenon in a natural setting.

\section{Data Collection and Research Design}

The data collection includes face-to-face semistructured, focused interviews, information provided on the company web sites, and other documents provided by the companies. The interviews were conducted with CEOs or managers that had a key role in the adoption and implementation of e-commerce. To increase reliability an interview protocol was used and a case study database was developed(Yin, 2003). The questions of the protocol were divided into two parts. Part one captured company background information such as the type of business, revenues, number of employees. Part two focused on gaining information about ecommerce adoption, web page sophistication, type and role of leadership in e-commerce adoption.

Triangulation has been achieved by visiting and analyzing each company web site before and after the interview and by analyzing annual reports and other material provided by the companies.

The questionnaire was pre-tested and minor revisions were made after the first interview. Each interview lasted between one and one and a half hour. All interviews were tape-recorded and transcribed. Notes were also taken during the interviews. Following Yin (2003) the data were analyzed by following the "general strategy of relying on theoretical orientation" of the case. Specific analytic techniques included putting information into different arrays, making matrixes of categories and placing evidence within such categories (Yin, 2003; Miles and Huberman, 1994).

\section{Company Selection Process}

The companies were selected on the basis of representativeness of the region industrial sectors and accessibility according to the following criteria: 
1. The companies should have already implemented e-business or were planning to do so in the near future, thus being adopters or prospective adopters.

2. They should be registered companies, could be classified as SMEs according to the number of employees and should be located in the same geographical region to ensure that external factors such as government policy, availability of support services, and education of the available workforce were the same.

3. The companies could belong to different business sectors including high-tech/knowledge intensive sectors as these businesses have been shown to be more advanced in their use of Internet technologies then firms in other business sectors (Drew, 2003). Here the assumption has been made that 1) a sample of companies belonging to different business sectors would lead to more variety in the data regarding leadership in e-commerce adoption then a sample of companies belonging to the same sector; 2) companies in the high tech/knowledge intensive sectors, being ahead of others in e-commerce adoption, could provide interesting insights for prospectors and laggards (Lertwongsatien and Wongpinunwatana 2003).

A research assistant at Queensland University of Technology, who in advance had been instructed about the objective of the study and the companies'selection criteria helped in contacting and selecting the sample companies. Due to the companies' wish, the company names are kept undisclosed.

\section{COMPANIES BACKGROUND}

The age of the firms ranged from 6 to 40 years. Even though there is a wide spreading among the companies with regard to the number of employees, the spreading is very small in terms of revenues, which are between 15 and 20 million Australian dollars. One company however did not provide any financial information. The firms had a wide range of experience with e-commerce. One company (A3) offered the capability to download software components from the web site, however it was not charging for it yet. The project was still at experimental stage, but the company was planning to charge for it in the future if it was a success. A2 offered online training and online customer support on the web site. They had traded products on the web site in the past, but it turned out to be a mistake mainly due to the complexity of their products. A2 has an Intranet which proved to be quite a useful tool for knowledge management and sharing. A summary of the companies' characteristics is provided in Table 2 .

Company A 1 is in the business of site and facilities management. It has existed since 1964, but it had been privatized at the beginning of 2000 . The company has 35 employees and yearly revenues of 15-16 millions Australian dollars. At the time of the interview, A1 had a web site from which it was possible to download company information and contained a database of tenants. However the company was investigating the possibility of implementing an advanced e-commerce platform in order to become a service provider to the tenants. The idea to adopt e-commerce came from the CEO/owner of the company.

The second company (A2) develops financial service software, and was established in 1983. It is privately owned by 4 people. The CEO owns 80 percent of the company and has been the one initiating the e-commerce project. It has an EDB department of 5 people. A2 offers online customer 
Table 2. Characteristics of the companies

\begin{tabular}{|c|c|c|c|c|c|c|}
\hline Firm & $\begin{array}{l}\text { Business } \\
\text { Type }\end{array}$ & $\begin{array}{r}\text { Years in } \\
\text { business }\end{array}$ & $\begin{array}{c}\text { Number } \\
\text { of employees }\end{array}$ & $\begin{array}{l}\text { Leadership } \\
\text { Style }\end{array}$ & $\begin{array}{c}\text { Yearly } \\
\text { revenues } \\
\text { in AUS }\end{array}$ & $\begin{array}{c}\text { E-commerce Platform } \\
\text { Facilities }\end{array}$ \\
\hline A1 & $\begin{array}{l}\text { Site and facilities } \\
\text { Management }\end{array}$ & 40 & 35 & $\begin{array}{l}\text { Directive/consul- } \\
\text { tative }\end{array}$ & 16-17 Millions & $\begin{array}{l}\text { Presently the web site provides } \\
\text { info and contains a database } \\
\text { of tenants. Were planning to } \\
\text { implement a full e-commerce } \\
\text { platform. }\end{array}$ \\
\hline A2 & $\begin{array}{l}\text { Financial Service } \\
\text { Software Consultant }\end{array}$ & 20 & 140 & $\begin{array}{l}\text { Directive/consul- } \\
\text { tative }\end{array}$ & 19-20 Millions & $\begin{array}{l}\text { Web site supports online cus- } \\
\text { tomer support, online training, } \\
\text { and online customer relation- } \\
\text { ship management. Traded } \\
\text { online in the past. }\end{array}$ \\
\hline $\mathbf{A 3}$ & Consulting & 6 & 3 & $\begin{array}{l}\text { Directive/consul- } \\
\text { tative }\end{array}$ & No Data & $\begin{array}{l}\text { Possibility to download trial } \\
\text { software from the web site } \\
\text { for free. Plans to make clients } \\
\text { paying for it in the future. }\end{array}$ \\
\hline A4 & $\begin{array}{l}\text { Design and Manufac- } \\
\text { turing }\end{array}$ & 32 & 80 & $\begin{array}{l}\text { Directive/consul- } \\
\text { tative }\end{array}$ & 15 Millions & $\begin{array}{l}\text { It is planning to adopt a full } \\
\text { e-commerce platform. There } \\
\text { was at that time disagreement } \\
\text { within top management about } \\
\text { what e-commerce features to } \\
\text { support. }\end{array}$ \\
\hline
\end{tabular}

support to its clients as well as online training. In the past they had traded online, but they had stopped doing so, mainly due to the nature of their products which are too complicated with a lot of ways they can be configured often depending on the customer business model. It might have helped if they had taken a more gradual approach to e-commerce.

The third company (A3) is in consulting and serves SMEs, larger size companies and government departments, such as the department of education. It is possible to download some software application components from the web side for trial by the client companies, but the company does not charge for it yet. They plan to do so in the future, if it becomes a success.

The fourth company (A4) was established in 1971, and manufactures point of sale objects such as displays and illuminated signs. They designed and made the products in house. They regularly purchased office supplies from online catalogues as well as raw material and at the time of the interview had a very basic e-commerce platform.
They were planning to develop more sophisticated e-commerce in the near future, but at that time there was disagreement in the top management about what e-commerce features to support.

\section{ANALYSIS AND RESULTS}

\section{Leadership in E-Commerce Adoption}

Importance of Leadership. The first main result of this study is that leadership is important in order for companies to adopt e-commerce. As discussed in the theoretical background, an important leadership role is setting a direction, a vision for the company in specific domains. In e-commerce adoption, leadership implies that managers have the intuition that e-commerce will bring some benefits that can justify the investment, even though there is no certainty on the return on investment as showed by the following citation: 
At that time (when we decided to adopt) we had some ideas about benefits, but we did notrealize the extent of the benefits until when we started using it for some time (Financial Manager, A1")

Another important role of leadership is aligning people and departments in such a way that everybody in the company supports the established vision. For example in A2, this is achieved by empowering the marketing department to be responsible for the content of the web page and to advise top management about what to do as showed by the following statement:

It is mainly the marketing department (3 people) that is responsible for Home page content and development and to make suggestions to the CEO and top management.....(Manager, A2)

Another statement showing the visionary leadership in SMEs' e-commerce adoption is the following:

"We have adopted Internet ..because we wanted to say we exist and this is what we want to do, to enhance our own branding and marketing; we wanted to be out there on the web..((Financial Manager, A1).

Leadership styles. The second main result of the study is that the predominant style of leadership in SMEs' e-commerce adoption is the directive, with some indications that the leadership style is moving from directive to consultative or a combination of both. Top management consults both with company employees and external consultants. For example in A1, initially the initiative had been taken by the CEO, who had mainly showed a directive form of leadership, but lately he was changing towards a more consultative leadership style as the following citation shows:

It was the CIO (that decided to adopt e-commerce)... he had a lot of clients and then decided to go with Internet, see ... the management decides... Only now management starts listening to suggestions from employees.. (Manager, A1)

The same was the case in A4:

..Onlynow management starts listening to suggestions from the EDB department..(Manager, A4)

Usually top management consult with employees about how to go to implement e-commerce in the company (e.g. what changes to be made and what features to support) only after the decision to adopt has been made. However, the employees are also involved in setting goals of relevance to their expertise area or responsibility, even though only to a limited extent (A1, A2, A3, A4) as the following citations shows:

...Employees also can make suggestions on web sites ...(Manager, A2)

In $\mathrm{A} 2$, there had been an employee that on her own initiative started analyzing competitors' web sites and found out that they were more user friendly than their own. Top management decided then to change their web site after her suggestion to make the web site more user-friendly and easy to use and operate. In all the four companies interviewed, top management considers e-commerce as a strategic innovation opportunity that could benefit or damage the company and as such it is carefully considered and discussed both internally to the company and with external consultants. For example in A4 the CEO and other top managers had had much discussion about future e-commerce plans, but they were disagreeing about its strategic impact and therefore about what to do.

There is big disagreement in management about what should be put in it (the web site). You are giving a lot of importance to the web page. ..(Manager, A4) 
Organizational change. Regarding organizational change as a consequence of e-commerce adoption, it can be concluded that all the four organizations interviewed are mostly in a stage of "Fine Tuning". Organizational change due to e-commerce adoption is an ongoing process characterized by fine tuning occurring in different places or departments in the organization. Personnel is being developed and trained to suit the organizational adoption of e-commerce and some groups are formed within the organization to focus on e-commerce. For example, in A2 the two people in the marketing department had the responsibility of taking care of the structure and content of the web page and to advise top management about what to do or what changes to make. However some sign of "incremental adjustment" are also found. For example A2 offers online customer support to its clients as well as online training, which has changed some processes in the organization. Also A1 was investigating the possibility of implementing an advanced e-commerce platform in order to become a service provider to the tenants, which would have expanded the type of business the company was in to embrace e-business.

\section{DISCUSSION OF FINDINGS}

This study shows that the role of leadership is essential in e-commerce adoption. These results support the findings of other studies where top management support is important in e-commerce adoption (e.g. Lertwongsatien and Wongpinunwatana, 2003; Mirchandani and Motwani, 2001). However, if previous studies (e.g. Thong, 1999; Thong and Yap, 1995) show that the CEO is generally the single point of authority, usually does not share information with other organization's employees and is the only one with access to the information needed to identify new opportunities, this study shows that CEO's leadership styles are moving from a directive to a more consultative type ofleadership style by discussing e-commerce adoption with other managers, company's employees and consultants. This is in line with the results of the study conducted by Cope and Waddell (1994), where by auditing leadership styles in e-commerce in Australia they found out that by far the majority was consultative with very little collaborative and directive, but surprisingly more coercive. Top management and the CEO are interested in the employees' knowledge, whether it is about customer needs as for example in A2, IT knowledge as for example in A1 or simply needs for some e-commerce or IT applications as in A3. CEOs and top management use such knowledge as input to their decision making. These results could be explained by the complexity of e-commerce technologies and by the lack of specialized ecommerce knowledge by the CEO.

Furthermore this study shows that e-commerce adoption is based on top management vision and planned, strategic decision making. That is the adoption of e-commerce is not happening by chance as for example due to the son or a friend of the CEO/owner being acquainted with Internet as found in other studies (e.g. Poon and Swatman, 1999) or by using an ad hoc approach as showed by Marshall et al. (2000). This could be due to the complexity of implementing e-commerce.

The study finds that companies are starting making an "informal" plan or strategy for e-commerce adoption as also found by Drew (2003). The importance of a strategic approach to e-commerce adoption is supported by the experience of A2, which had to reduce the e-commerce capabilities when it realized that their products were too complicated to be configured and sold on the web. Therefore also the importance of "fit" between the technology and the business the company is in, as also pointed out by Mirchandani and Motwani (2001).

Finally this study shows that the managers/ owners are recognizing the importance of the knowledge generated within the company. New theories of strategic management are empha- 
sizing knowledge and the dynamic aspects of organizational knowledge creation as important in increasing the firms' innovation capability and competitive advantage (E.g. Nonaka, 1994). These theories argue that while new knowledge is developed by individuals, management plays a critical role in articulating and applying this knowledge (Grant, 1996).

\section{FUTURE TRENDS: IMPLICATIONS FOR PRACTICE}

The main implications for SMEs' managers and owners is that adoption of e-commerce offering more advanced features than just presentation of company's information on the web site for marketing purposes or use of e-mail, requires first of all that managers show leadership in this field. Leadership is especially important in establishing a vision and enforcing organizational rules and policy to facilitate e-commerce adoption in the organization (e.g. Scupola, 2008). Another implication for management is that it is important to value and take into consideration the employees' knowledge and suggestions both in the strategic planning phase and in the implementation phase of e-commerce, thus adopting a leadership style that has at least some traits of the consultative type. This is mainly due to the complexity of ecommerce and the fact that adopting e-commerce implies the allocation of resources and investments that are more substantial than just establishing an Internetconnection or developing and maintaining a simple static web page.

\section{CONCLUSIONS AND LIMITATIONS}

This study has contributed to understand leadership and leadership styles in e-commerce adoption in small and medium size enterprises. The main findings can be summarized as follows: top management and CEO e-commerce leadership are determinants for e-commerce adoption; the predominant e-commerce leadership style in Australian SMEs is directive moving towards consultative thus taking into consideration both the organizational knowledge and the consultants' knowledge in the decision to adopt or implement e-commerce.

Even though the study presents some interesting results, it is however not free from limitations. First of all the number of sample companies is limited and belong to different business sectors among which high tech industries/knowledge intensive industries. Therefore it might be difficult to generalize the results from this study to specific industrial sectors. Second, all the sample companies were located in a metropolitan area. Therefore it might be difficult to generalize the results to regional areas, defined as geographical areas located outside metropolitan centres and major cities. Nevertheless, this research gives some interesting insights into the role of leadership in SMEs e-commerce adoption. The results of this study can be useful to researchers, owners and practicing managers of small and medium size enterprises wishing to adopt e-commerce.

Finally, the limitations of this study can also be considered as the starting point for further research. For example, the study could be replicated in service companies or regional areas, and further research could investigate the emergence of strategies or the role of organizational knowledge in e-commerce adoption in SMEs. Also a follow up survey to a large sample of SMEs could strengthen the results of this study.

\section{REFERENCES}

Bower, J. L., \& Gilbert, C. G. (2007). How managers' everyday decisions create or destroy your company's strategy. Harvard Business Review, 2007(February), 72-79. 
Chau, P. Y. K., \& Tam, K. Y. (1997). Factors affecting the adoption of open systems: An exploratory study. MIS Quarterly, 21(1), 1-24. doi:10.2307/249740

Cragg, P., \& King, M. (1993). Small firm computing: Motivators and inhibitors. MIS Quarterly, 47-59. doi:10.2307/249509

Creswell, J. W. (1998). Qualitative inquiry and research design. Thousand Oaks, CA: Sage Publications.

Drew, S. (2003). Strategic uses of e-commerce by SMEs in the east of England. European Management Journal, 21(1), 79. doi:10.1016/S02632373(02)00148-2

Goleman, D. (2004). What makes a leader? Harvard Business Review, 82-91.

Grandon, E., \& Pearson, J. M. (2003). Strategic value and adoption of electronic commerce: An empirical study of Chilean small and medium businesses. Journal of Global Information Technology Management, 6(3).

Grant, R. M. (1996). Towards a knowledge-based theory of the firm. Strategic Management Journal, 17, 102-122.

Iacovou, C. L., Benbasat, I., \& Dexter, A. S. (1995). Electronic data interchange and small organizations: Adoption and impact of technology. MIS Quarterly, 19(4), 465-485. doi:10.2307/249629 Jago, A. G. (1982). Leadership: Perspectives in theory and research. Management Science, 28(3), 22. doi:10.1287/mnsc.28.3.315

Jeyaraj, A., Rottman, J., \& Lacity, M. J. (2006). A review of the predictors, linkages, and biases in IT innovation adoption research. Journal of Information Technology, 21(1), 1-23. doi:10.1057/ palgrave.jit.2000056

Kotter, J. (2001). What leaders really do. Harvard Business Review, (December): 85-96.
Kuan, K., \& Chau, P. (2001). A perception-based model of EDI adoption in small businesses using technology-organization-environment framework. Information \& Management, 38, 507-521. doi:10.1016/S0378-7206(01)00073-8

Kurnia, S., \& Johnston, R. B. (2000). The need for a processual view of inter-organizational systems adoption. The Journal of Strategic Information Systems, 9(4), 295-319. doi:10.1016/S09638687(00)00050-0

Lertwongsatien, C., \& Wongpinunwatana, N. (2003). E-commerce adoption in Thailand: An empirical study of small and medium enterprises (SMEs). Journal of Global Information Technology Management, 6(3), 67-83.

Marshall, P., Sor, R., \& McKay, J. (2000). The impacts of electronic commerce in the automobile industry: An empirical study in Western Australia. In [Berlin, Germany: Springer Verlag.]. Proceedings of the CAiSe, 2000, 509-521.

Mirchandani, D. A., \& Motwani, J. (2001). Understanding small business electronic commerce adoption: An empirical analysis. Journal of Computer Information Systems, (Spring): 70-73.

Nonaka, I. (1994). A dynamic theory of organizational knowledge creation. Organization Science, 5(1). doi:10.1287/orsc.5.1.14

OECD. (2002). Measuring the information economy 2002. Retrieved August 20, 2004, from http://www.oecd.org

Palvia, P. C., \& Palvia, S. C. (1999). An examination of the IT satisfaction of small-business users. Information \& Management, 35(3), 127-137. doi:10.1016/S0378-7206(98)00086-X

Poon, S., \& Swatman, P. M. C. (1999). An exploratory study of small business Internet commerce issues. Information \& Management, 35(1), 9-18. doi:10.1016/S0378-7206(98)00079-2 
Premkumar, G., \& Ramamurthy, K. (1995). The role of interorganisational and organizational factors on the decision mode for adoption of interorganisational systems. Decision Sciences, 26(3), 303-336. doi:10.1111/j.1540-5915.1995. tb01431.x

Ready, D. (2004). Leading at the enterprise level. MITSloan Management Review, 45(3), 87-91.

Rogers, E. M. (1995). Diffusion of innovations ( $4^{\text {th }}$ ed.). New York: The Free Press.

Sabherwal, R., Jeyaraj, A., \& Chowa, C. (2006). Information system success: Individual and organizational determinants. Management Science, 52(12), 1849-1864. doi:10.1287/ mnsc. 1060.0583

Scupola, A. (2003). The adoption of Internet commerce by SMEs in the south of Italy: An environmental, technological and organizational perspective. Journal of Global Information Technology Management, 6(1), 51-71.
Thong, J., \& Yap, C. (1995). CEO characteristics, organizational characteristics and information technology adoption in small business. Omega . International Journal of Management Sciences, 23(4), 429-442.

Thong, J. Y. L. (1999). An integrated model of information systems adoption in small business. Journal of Management Information Systems, 15(4), 187-214.

Tornatzky, L. G., \& Fleischer, M. (1990). The processes of technological innovation. Lanham, MD: Lexington Books.

Zaleznik, A. (2004). Managers and leaders: Are they different? Harvard Business Review, (January): 74-97. 